\title{
Use of Recycled Concrete Aggregate in Controlled Low-Strength Material (CLSM)
}

\author{
Naganathan, S.1, Mustapha, K.N. ${ }^{1}$, and Omar, H. ${ }^{1}$
}

\begin{abstract}
Use of recycled concrete aggregate (RCA) is getting importance as it minimizes the use of fresh materials and eliminates waste disposal. One of the uses of RCA is as aggregate in Controlled Low Strength Material (CLSM). This paper reports the results of the investigation done on the use of RCA in CLSM. Various mixtures of CLSM were made using RCA, fly ash, and cement. Tests for workability, bleeding, density, strength, water absorption, sorption, and ultrasonic pulse velocity (UPV) were conducted. Results show that the compressive strength ranged from $1.71 \mathrm{MPa}$ to $4.92 \mathrm{MPa}$, fresh density from $1879 \mathrm{~kg} / \mathrm{m}^{3}$ to $1998 \mathrm{~kg} / \mathrm{m}^{3}$. The strength of CLSM increases with the increase in fly ash; water absorption and bleeding decrease with increase in fly ash. It is concluded that the RCA has potential to be used in CLSM and the addition of fly ash enhances the performance.
\end{abstract}

Keywords: Controlled low strength material, recycled concrete aggregate, fly Ash, sorption, UPV.

\section{Introduction}

As defined by American Concrete Institute ACI Committee 229, Controlled Low Strength Material (CLSM) is a self compacting cementitious material that is in a flowable state at the time of placement and has specified compressive strength of $8.3 \mathrm{MPa}$ or less at the age of 28 days [1]. The primary advantage of CLSM is its ability to consume large volume of waste materials which will contribute to sustainability. Many waste materials such as bottom ash from industrial waste, glass, quarry fines etc. are successfully used in CLSM [2]. The fresh density values of CLSM mixes made with bottom ash were in the range of $1528-1560 \mathrm{~kg} / \mathrm{m}^{3}$. The strength of CLSM mixes tested is in the range of $0.125-1.731$ $\mathrm{MPa}$. For the CLSM to be excavatable, the strength should be less than 1.7 MPa. Hence the designed mixes in this study are suitable as an excavatable CLSM. Also, w/c and cement over bottom ash (c/BA) have influence on the bleed capacity of CLSM. More water and less cement addition gives more bleeding [2].

Fly ash (FA) is an essential ingredient in CLSM to make it flowable. Hongzhu [3] conducted experiments on the properties of air-entraining concrete containing FA with $25 \%$ replacement to Portland cement. It is reported that the compressive strength would decrease with the increased water content, increased water binder ratio and increased drying shrinkage

\footnotetext{
${ }^{1}$ Department of Civil Engineering, Universiti Tenaga Nasional, Jalan Ikram-Uniten, 43000 Kajang, Selangor, MALAYSIA.

Email: sivan@uniten.edu.my,

Tel: +60389212257, Fax: +60389212116.
}

Note: Discussion is expected before June, $1^{\text {st }} 2012$, and will be published in the "Civil Engineering Dimension" volume 14, number 2, September 2012.

Received 11 August 2011; revised 17 November 2011; accepted 05 February 2012. when the fineness of FA decreased; and the compressive strength would increase with the decreased water content and decreased water binder ratio when the fineness of FA increased.

Successful application of recycled aggregate in construction projects has been reported in some European and American countries, as reviewed by Desmyster and Vyncke [4]. In the first case, a total of $11000 \mathrm{~m}^{3}$ of concrete, in which $20 \%$ of the coarse aggregates were replaced by recycled aggregates, were used in all parts of the structures. Another reported case involved the use of $4000 \mathrm{~m}^{3}$ of ready mixed concrete, which was prepared with recycled aggregates obtained from crushed concrete railway sleepers to replace $40 \%$ of the coarse aggregates [4]. It should be noted that in these cases recycled aggregates were used only to replace the coarse natural aggregates. The Recycled Concrete Aggregate (RCA) can be potentially tried as CLSM applications. This will enable the use of wastes whereby increasing the Green Building Index (GBI) values of buildings. Points are usually awarded to a building to increase the GBI rating if waste materials are used in the construction. The performance of RCA in CLSM has been investigated in this research. Various mixtures of CLSM were made using RCA, FA, and cement. Tests for workability, bleeding, density, strength, water absorption, sorption, and ultrasonic pulse velocity (UPV) were conducted [5].

\section{Experimental Methods}

\section{Material Used}

Ordinary Portland Cement (OPC) conforming to MS522 Part1: 1989 [6] was used for all mixtures. All the cement used was from the same source, and met the requirements of MS522 Part1: 1989. Fly ash is 
Table 1. Chemical Characterization of Fly Ash and Cement

\begin{tabular}{ccccccccccccc}
\hline \multirow{2}{*}{ Material } & \multicolumn{10}{c}{ Chemical Composition (\%) } \\
\cline { 2 - 12 } & $\mathrm{SiO}_{2}$ & $\mathrm{Al}_{2} \mathrm{O}_{3}$ & $\mathrm{FeO}_{2} \mathrm{O}_{3}$ & $\mathrm{CaO}$ & $\mathrm{Mn}_{3} \mathrm{O}_{4}$ & $\mathrm{Na} 2 \mathrm{O}$ & $\mathrm{KiO}_{2} \mathrm{O}$ & $\mathrm{MgO}$ & $\mathrm{SO}_{3}$ & $\mathrm{P}_{2} \mathrm{O}_{5}$ & $\mathrm{MgO}$ \\
\hline Fly Ash & 65.50 & 24.40 & 3.50 & 1.80 & $<0.02$ & 0.24 & 0.95 & 1.60 & 0.34 & 1.20 & 0.42 & - \\
Cement & 21.54 & 5.32 & 3.63 & 63.66 & - & - & - & - & - & 2.18 & - & 1.08 \\
\hline
\end{tabular}

Table 2. Physical Properties of Fly Ash and Cement

\begin{tabular}{ccccc}
\hline \multirow{2}{*}{ Material } & \multicolumn{4}{c}{ Physical Composition } \\
\cline { 2 - 5 } & Loss in Ignition (\%) & $\begin{array}{c}\text { Blaine's Fineness } \\
\left(\mathrm{cm}^{2} / \mathrm{g}\right)\end{array}$ & Density $\left(\mathrm{kg} / \mathrm{m}^{3}\right)$ & $\begin{array}{c}\text { Specific Gravity } \\
\left(\mathrm{kg} / \mathrm{m}^{3}\right)\end{array}$ \\
\hline Fly Ash & - & - & 1155.68 & 2.06 \\
Cement & 2.50 & 3500.00 & 1367.00 & 3.15 \\
\hline
\end{tabular}

taken from Kapar Energy Power Plant, class of FA is class $\mathrm{F}$ fly ash because Calcium Oxide are below 5\%. The chemical composition of the fly ash and cement are shown in Table 1 and the physical properties are given in Table 2.

The recycled concrete aggregate (RCA) was collected by crushing the waste cubes and cylinders for the laboratory by hammering and sieving the contents through a $10 \mathrm{~mm}$ sieve. The aggregate that passed through the sieve was collected and used in the mixture. The fineness modulus of RCA was 4.11 and the grading curve is given in Figure 1. Other physical properties like absorption etc. need to be evaluated for further assessment of its influence on the properties of CLSM.

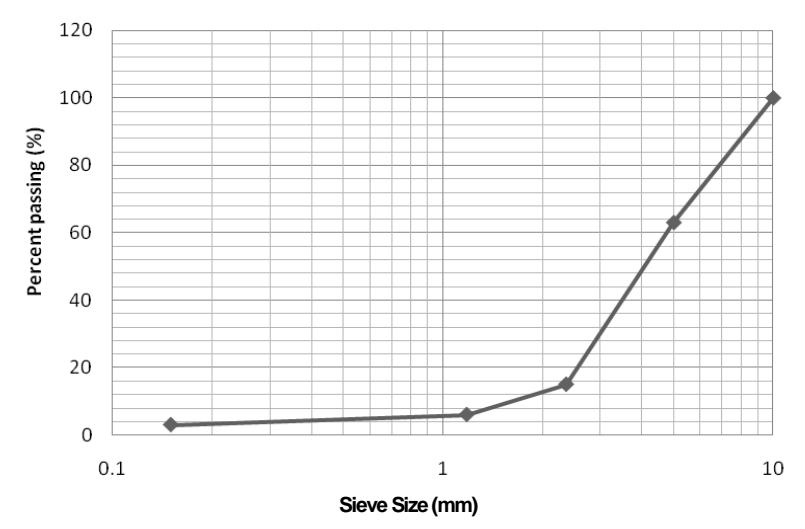

Figure 1. Grading Curve for RCA

\section{Mix Proportion}

The mix proportions adopted in the investigation is given in Table 3.

\section{Casting and Testing}

The mixes were weighed according to the mixing ratio. Amount of the weighed RCA, fly ash and cement is mixed dry in the mixer for 1 minute. Then the water is added until the mix is flow-able, the flowability test is conducted according to ASTM D
6103 - 04 [7]. The flowability of all the mixtures were kept at $200 \pm 10 \mathrm{~mm}$. The mix was then poured into the moulds, the sides of the moulds were tapped gently with a ruler to eliminate any trapped air voids. The samples were kept in laboratory conditions until the day of testing.

Table 3. Mix Proportion

\begin{tabular}{cccccccccc}
\hline $\begin{array}{c}\text { Mix } \\
\text { ID }\end{array}$ & $\begin{array}{c}\text { RCA } \\
\left(\mathrm{kg} / \mathrm{m}^{3}\right)\end{array}$ & $\begin{array}{c}\text { FA } \\
\left(\mathrm{kg} / \mathrm{m}^{3}\right)\end{array}$ & $\begin{array}{c}\text { Cement } \\
\left(\mathrm{kg} / \mathrm{m}^{3}\right)\end{array}$ & $\begin{array}{c}\text { Water } \\
\left(\mathrm{kg} / \mathrm{m}^{3}\right)\end{array}$ & & & & & \\
& $\mathbf{1}$ & 976.23 & 487.71 & 49.18 & 373.28 & 7.59 & 0.76 & 0.70 & 0.55 \\
$\mathbf{2}$ & 832.87 & 624.48 & 62.94 & 469.51 & 7.46 & 0.74 & 0.68 & 0.82 \\
$\mathbf{3}$ & 696.49 & 696.49 & 70.18 & 521.40 & 7.43 & 0.73 & 0.68 & 1.10 \\
$\mathbf{4}$ & 607.65 & 759.18 & 76.53 & 557.90 & 7.29 & 0.70 & 0.67 & 1.38 \\
$\mathbf{5}$ & 794.00 & 396.67 & 79.33 & 608.47 & 7.67 & 0.79 & 1.28 & 0.60 \\
$\mathbf{6}$ & 650.82 & 487.98 & 97.81 & 748.09 & 7.65 & 0.77 & 1.28 & 0.90 \\
$\mathbf{7}$ & 534.08 & 534.08 & 106.73 & 809.87 & 7.59 & 0.75 & 1.26 & 1.20 \\
$\mathbf{8}$ & 454.58 & 567.94 & 113.74 & 859.54 & 7.56 & 0.73 & 1.26 & 1.50 \\
\hline
\end{tabular}

Test for bleeding was done according ASTM 940 [8]. It is done on fresh CLSM, $1000 \mathrm{~mL}$ measuring jar are needed for this test. The test done by filling 800 $\mathrm{mL}$ of fresh CLSM in the jar, the jars then closed and left in room temperature for one to four hours until the water level is stabilized. The volume of the bleed then is accumulated over the solid particles of CLSM. The bleed then be expressed in percentage from the initial volume of the CLSM.

The compression test was done according to BS 1881 - 116 [9]. The test was carried out on 7, 14, and 28 days. The test is done in cube condition for the concrete. The size of the cubes was $70 \mathrm{~mm}$ and the maximum size of the recycled concrete aggregate is $10 \mathrm{~mm}$. Universal testing machine was used for the testing. The loading rate was kept low at 1 $\mathrm{N} / \mathrm{mm}^{2} / \mathrm{sec}$. This will enable the test to be more accurate as it is a low strength material. Three samples of cube were tested for each of the day and the average value reported.

Sorption test is used to measure the rate of water absorption by capillary suction of unsaturated sample that comes in contact with water at 28 days. 
The tests are done by referring to Byrami [10]. The samples were measured by keeping the cube on two $6 \mathrm{~mm}$ rod supports in a tray, and maintaining the bottom 2 to $5 \mathrm{~mm}$ height of the cube in contact with water. The increase in mass of cubes was recorded every 30 minutes up to 4 hours from the start of the test. Water absorption test was done according to BS 1881 - Part 122, [11]. First the samples were kept in an oven for 24 hours at $112^{\circ} \mathrm{C}$ and then cooled down to room temperature for testing. Then the samples were immersed in a water tub for 1 hour. Then the weight of the sample was noted and water absorption was calculated.

Ultrasonic pulse velocity (UPV) test was done according to BS 1881 - Part 203 [12]. UPV is used to test structural elements to check the homogeneity of concrete and the presence of cracks, to identity any voids and other imperfections from the concrete [13]. This test also can be used to identify the changes in concrete structure through time. The pulse velocity in concrete is related to the strength of the concrete. This test runs on 28 days of CLSM cube sample. Three samples of each ratio being tested on every side of the cube not include the top and bottom of the cube. Test is done in direct measurement for every cube sample.

\section{Results and Discussion}

The properties that were observed in fresh and hardened states are given in Table 4. It is noted that the fresh density varied from $1879 \mathrm{~kg} / \mathrm{m}^{3}$ to 1998 $\mathrm{kg} / \mathrm{m}^{3}$, and the hardened density varied from 1726 $\mathrm{kg} / \mathrm{m}^{3}$ to $1896 \mathrm{~kg} / \mathrm{m}^{3}$. The range of density values for CLSM with fly ash as filler material is $1500 \mathrm{~kg} / \mathrm{m}^{3}$ to $1900 \mathrm{~kg} / \mathrm{m}^{3}$ [14]. Hence it is concluded that the CLSM mixtures developed in the investigation has a comparable density values.

The fresh density values for all the mixtures ranged from $1885 \mathrm{~kg} / \mathrm{m}^{3}$ to $1998 \mathrm{~kg} / \mathrm{m}^{3}$. The range of density for sand sandy loam soils is $1200 \mathrm{~kg} / \mathrm{m}^{3}$ to 1800 $\mathrm{kg} / \mathrm{m}^{3}$ [15]. Hence the CLSM produced are higher in density comparable to that of sand and sandy loam soil with regard to density. The relationship between fresh density and powder to RCA ratio (p/RCA) is shown in Figure 2. It is indicated that fresh density decreases with increase in w/c and increases with increase in $\mathrm{p} / \mathrm{RCA}$. Addition of more water reduces the weight of the contents and addition of more solids in the form of powder and RCA increases the weight and hence the increase in density. This is also evident from Figure 3 which depicts the relationship between fresh density and water absorption. Water absorption is higher for mixtures with less fresh density. When more water is added, the fresh density is less which creates pores in the hardened matrix due to water evaporation and bleeding, and hence increasing the water absorption.

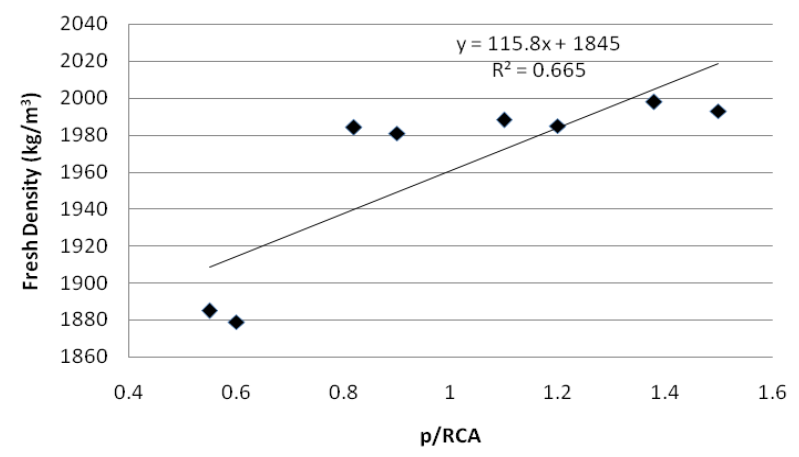

Figure 2. Relationship Between Fresh Density and p/RCA

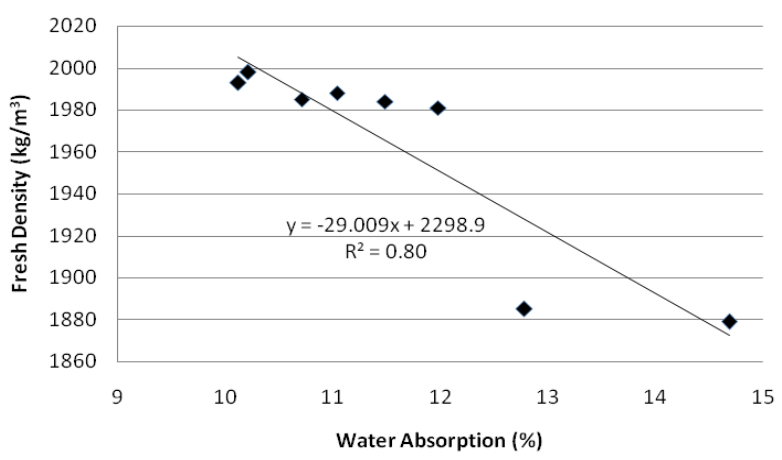

Figure 3. Relationship Between Fresh Density and Water Absorption

Table 4. Properties of CLSM

\begin{tabular}{|c|c|c|c|c|c|c|c|c|c|}
\hline \multirow{2}{*}{$\begin{array}{c}\text { Mix } \\
\text { ID }\end{array}$} & \multicolumn{3}{|c|}{$\begin{array}{l}\text { Compressive Strength } \\
(\mathrm{MPa}) \text { at day }\end{array}$} & \multirow{2}{*}{$\begin{array}{l}\text { Hardened Density } \\
\text { Day } 28\left(\mathrm{~kg} / \mathrm{m}^{3}\right)\end{array}$} & \multirow{2}{*}{$\begin{array}{c}\text { Water } \\
\text { Absorption (\%) }\end{array}$} & \multirow{2}{*}{$\begin{array}{l}\mathrm{UPV} \\
(\mathrm{m} / \mathrm{s})\end{array}$} & \multirow{2}{*}{$\begin{array}{l}\text { Sorption } \\
(\%)\end{array}$} & \multirow{2}{*}{$\begin{array}{l}\text { Fresh Density } \\
\left(\mathrm{kg} / \mathrm{m}^{3}\right)\end{array}$} & \multirow[t]{2}{*}{ Bleeding (\%) } \\
\hline & 7 & 14 & 28 & & & & & & \\
\hline 1 & 0.50 & 1.13 & 1.77 & 1726 & 12.78 & 994.04 & 12.94 & 1885 & 11.25 \\
\hline 2 & 1.28 & 1.96 & 2.19 & 1754 & 11.49 & 1282.05 & 9.95 & 1984 & 10.63 \\
\hline 3 & 1.28 & 2.15 & 3.24 & 1811 & 11.04 & 1438.26 & 9.20 & 1988 & 5.00 \\
\hline 4 & 1.12 & 2.60 & 4.05 & 1839 & 10.21 & 1478.35 & 6.65 & 1998 & 4.38 \\
\hline 5 & 0.74 & 1.51 & 2.09 & 1754 & 14.69 & 1100.98 & 12.22 & 1879 & 10.63 \\
\hline 6 & 1.22 & 2.05 & 2.37 & 1783 & 11.98 & 1220.15 & 9.87 & 1981 & 10.00 \\
\hline 7 & 1.46 & 2.28 & 3.34 & 1811 & 10.71 & 1563.55 & 8.40 & 1985 & 4.38 \\
\hline 8 & 1.35 & 2.73 & 4.63 & 1896 & 10.12 & 1529.39 & 6.71 & 1993 & 3.13 \\
\hline
\end{tabular}


The compressive strength of CLSM mixtures at 28 days varied from $0.5 \mathrm{MPa}$ to $4.63 \mathrm{MPa}$. According to ACI committee 229R [1], the compressive strength of CLSM should be less than $8.3 \mathrm{MPa}$. Hence the designed mixes in this study are suitable as excavatable CLSM. Figure 4 illustrates the relationship between strength and w/c. It shows that the strength is decreasing with the increase of water. This is because of the presence of excess water, which is not involved in the hydration process, forms internal voids especially water pockets at the transition zone between the cement paste and aggregate in the concrete matrix and weakens the bond between the concrete components, which is one of determining factors for the strength [16]. The relationship between strength and $\mathrm{p} / \mathrm{RCA}$ is shown in Figure 5. It is clear that the strength increases with the increase of powder content. This maybe because of the increase of powder in terms of FA and cement increases the paste in the mixture, and increases the bond of the mixture.

Water absorption result in this research ranged from $10.12 \%$ to $14.69 \%$. Water absorption is higher for mixtures with high w/c ratio. When more water is added, the fresh density is less which creates pores in the hardened matrix due to water evaporation and bleeding whereby increases the water absorption.

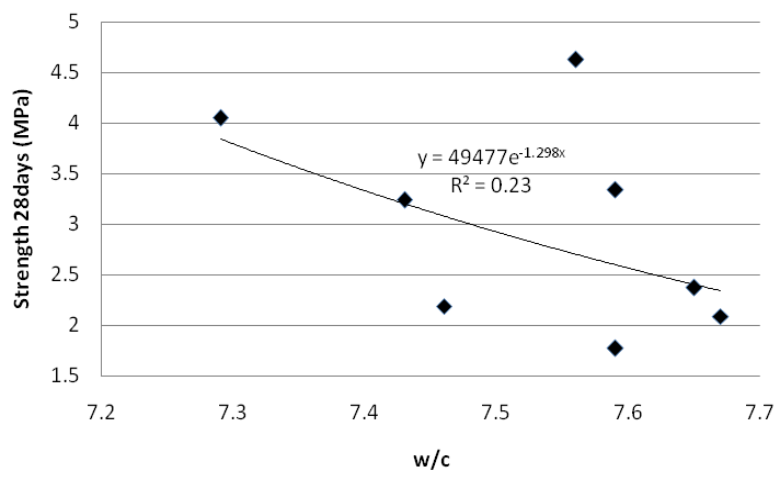

Figure 4. Relationship Between Strength and w/c

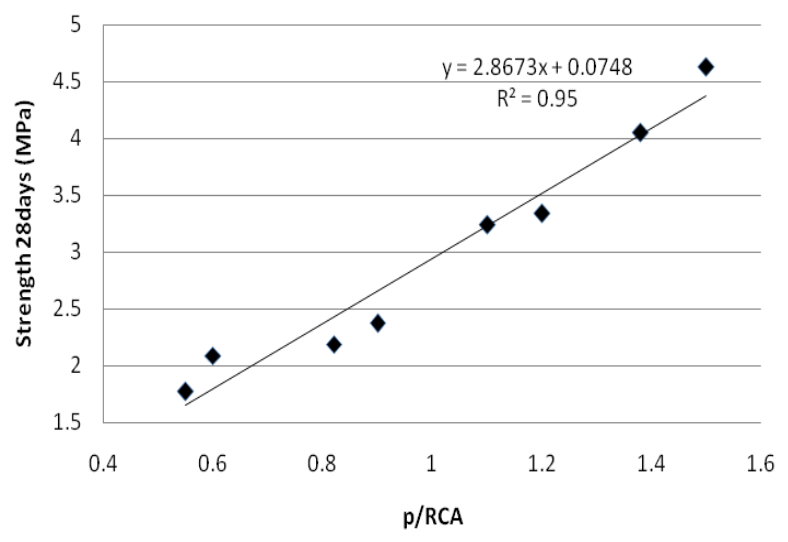

Figure 5. Relationship Between Strength and p/RCA
Figure 6 shows the relationship between water absorption and $\mathrm{p} / \mathrm{RCA}$. It is indicated that water absorption increases with increase in w/c and decreases with increase in p/RCA. Addition of more water reduces the weight of the contents and addition of more solids in the form of powder and RCA increases the weight and hence the increase in density. Addition of more solids in the form of powder is found to decrease the water absorption of the mixture in its hardened state. This is because fly ash fills the void in the mixture and reduces the water absorption through the cube capillary.

The bleed for the mixtures tested are from $3.13 \%$ to $11.25 \%$. It is observed that bleed increases with the increase of water in the mixture. This is because adding water more than that is needed for hydration is given out as bleed [2]. Figure 7 shows that bleeding of the mixture decreases with increase in $\mathrm{p} / \mathrm{RCA}$. This is cause of the increasing quantities of cement will reduce bleeding due to the absorption of excess water by fine particles [2]. Relationship between bleeding and sorption is linear as indicated in Figure 8.

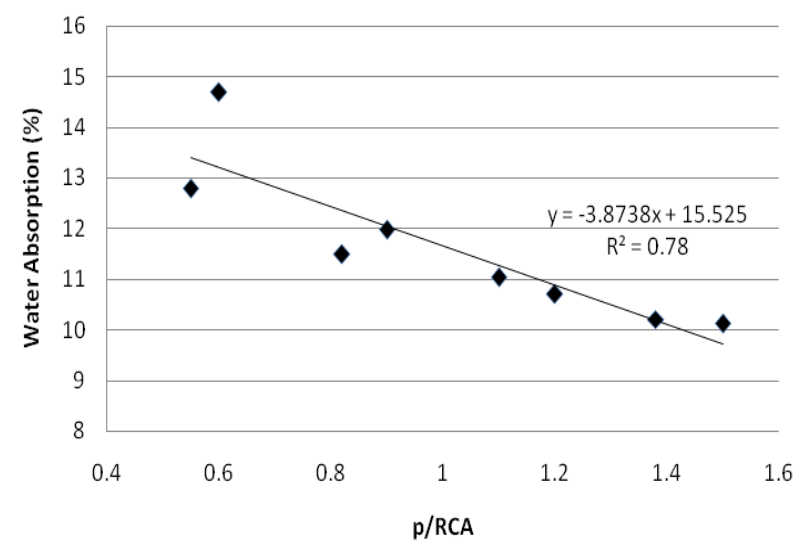

Figure 6. Relationship Between Water Absorption and $\mathrm{p} / \mathrm{RCA}$

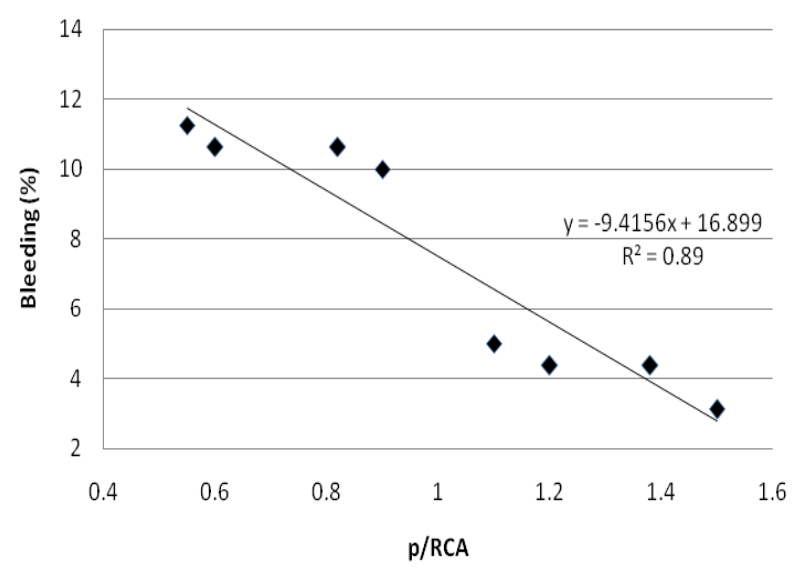

Figure 7. Relationship Between Bleeding and p/RCA 


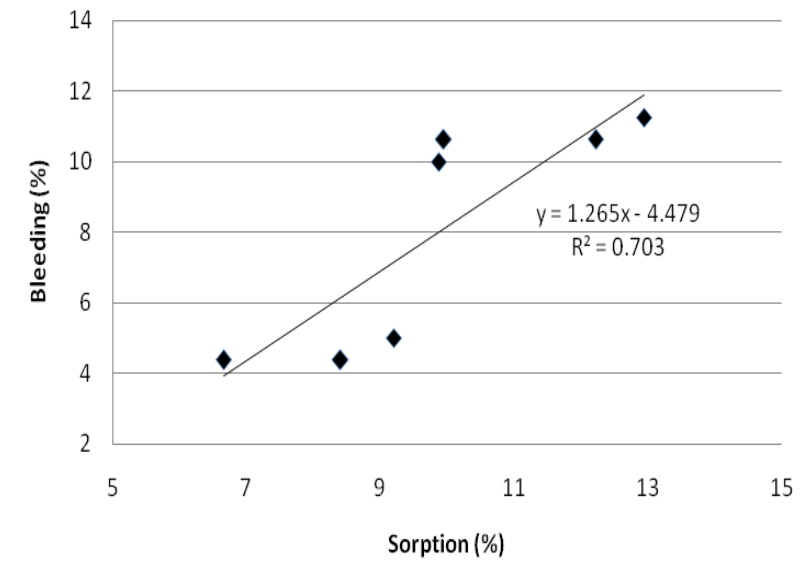

Figure 8. Relationship Between Bleeding and Sorption

The range results for UPV are between $994.04 \mathrm{~m} / \mathrm{s}$ to $1563.33 \mathrm{~m} / \mathrm{s}$. The UPV value for bricks is in the range of $1453 \mathrm{~m} / \mathrm{s}$ to $2758 \mathrm{~m} / \mathrm{s}$ [17]. The CLSM is a low strength and high porous material. Hence the UPV values obtained is considered acceptable for CLSM. Figure 9 shows relationship between UPV and strength. This is according to established fact that the higher UPV value, the higher is the strength and the quality [18].

The relationship between sorption and w/c is shown in Figure 10. It is indicated that sorption increases with increase in w/c and decreases with increase in $\mathrm{p} / \mathrm{RCA}$. Addition of more water reduces the weight and the bind of the contents. Addition of more solids in the form of powder and RCA increases the weight and hence the increase in density. The particles of fly ash fill the voids in the mixtures while cement will increase the paste between all the particles in the mixture. This causes the reduction in the capitarity and thus the sorption. Relationship between sorption and water absorption are linear which is shown in Figure 11.

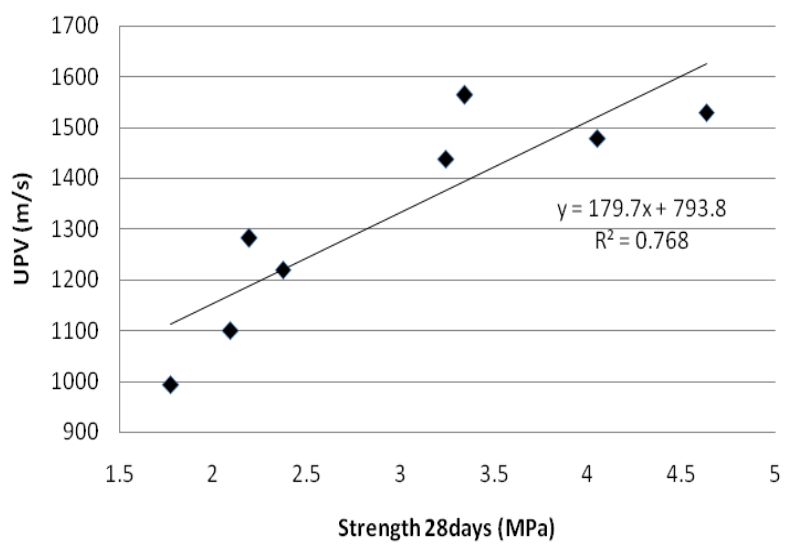

Figure 9. Relationship Between UPV and Strength

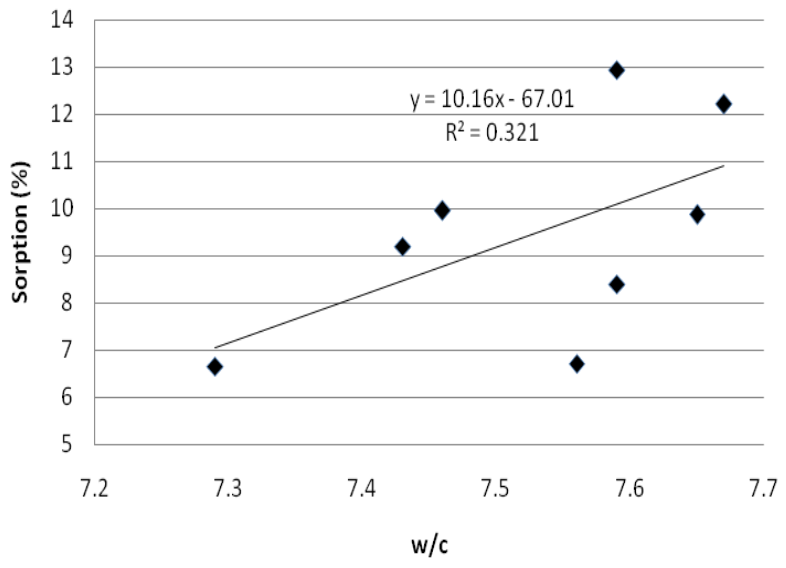

Figure 10. Relationship Between Sorption and w/c

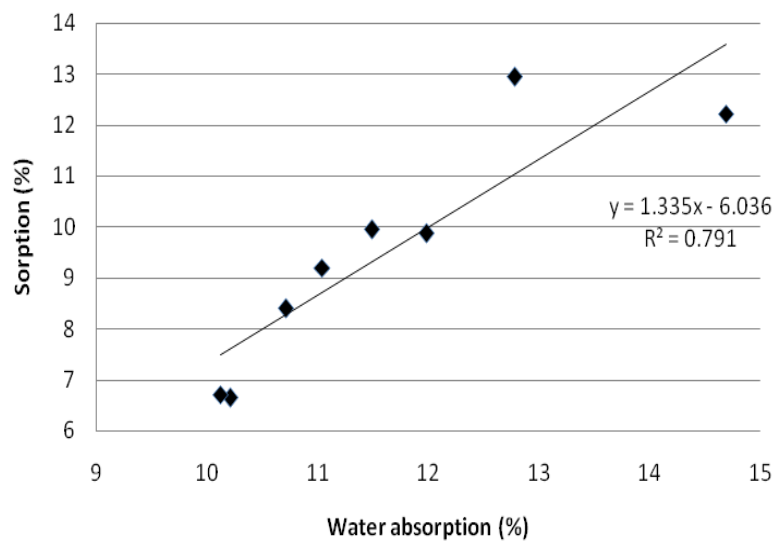

Figure 11. Relationship Between Sorption and Water Absorption

Based on the results obtained, the authors found that RCA and FA can be used successfully in CLSM applications. The mixtures can be designed based on the field requirements. Use of RCA and FA will contribute to sustainability and green technology in civil engineering. Further investigations are necessary to further understand the behavior of these materials in CLSM.

\section{Conclusion}

The following conclusions are made from the results obtained:

- Strength of the CLSM increases with the increase in cement and FA

- Fly ash is helping in reducing the water absorption of the CLSM in the hardened state.

- Increasing the powder content decreases the sorption of CLSM.

- Addition of cement increases strength and UPV.

- Use of RCA in CLSM application is viable and offers sustainable advantages. 
More detail investigation is necessary to arrive at more specific conclusions on the use of RCA in CLSM applications.

\section{References}

1. ACI committee 229R. Controlled Low-strength Materials, American Concrete Institute, Farmington Hills, MI, USA, 1999.

2. Razak H.A, Naganathan. S., Nadzriah A.H., Performance Appraisal of Industrial Waste Incineration Bottom Ash as Controlled LowStrength Material, Journal of Hazardous Materials, 172, 2009, pp. 862-867.

3. Quan, H., The Effects of Change in Fineness of Fly Ash on Air-Entraining Concrete, The Open Civil Engineering Journal, 5, 2011, pp. 124-131.

4. Desmyster J, Vyncke J, Use of Recycled Materials as Aggregates in Construction Industry (posters), Proceedings of the 1st ETNRecy, nety RILEM Workshop Paris: ETNRecy, Combined, Volume 2, Issue 3 and 4, 2000, pp. 2-6.

5. Rahardjati, R., Khamidi, M.F., and Idrus, A., The need of Material Resources Criteria in Green Building Assessment, 2nd International Conference on Environmental Science and Technology (ICEST 2011), 2011, pp. 2-4.

6. — MS 522: Part 1: 2003. Portland Cement (Ordinary and Rapid-Hardening): Part 1: Specification (Second revision). Department of Standards Malaysia, 2003.

7. ASTM D 6103-00. Standard Test Method for Flow Consistency of Controlled Low-Strength Material (CLSM), American Society for Testing and Materials, PA, USA, 2000.

8. ASTM 940. Standard Test Method for Expansion and Bleeding of Freshly Mixed Grouts for Preplaced-Aggregate Concrete in the Laboratory, American Society for Testing and Materials, PA, USA, 2003.
9. BS 1881-116. Testing Concrete, Method for Determination of Compressive Strength of Concrete Cube, British Standards Institution, 1983.

10. Byrami M., Rate of Absorption of Water by Litecrete Lightweight Concrete and Normal Concrete, Civil and Environmental Engineering, The University of Auckland. Ref: 10646.04, 2006.

11. BS 1881-Part 122, Testing Concrete, Method for Determination of Water Absorption. British Standards Institution, 1983.

12. BS 1881-Part 203, Testing Concrete, Recommendations for Measurement of Velocity of Ultrasonic Pulses in Concrete, 1986.

13. Civil Engineering Portal. Ultrasonic Pulse Velocity Method, Civil Engineering Test, 20072011. http://www.engineeringcivil.com/ultrasonicpulse-velocity-method.html.

14. U.S. Department of Transportation, User Guidelines for Waste and Byproduct Materials in Pavement Construction (Flowable Fill), Federal Highway Administration FHWA-RD-97-148, 2011.

15. Naganathan S, Razak HA, Nadzrian AH., Effect of Kaolin Addition on the Performance of Controlled Low-Strength Material using Industrial Waste Incineration Bottom Ash, Waste Manage Res, 28, 2010, pp. 848-860.

16. Wua, W., Zhang, W., and Ma, G., Optimum Content of Copper Slag as a Fine Aggregate in High Strength Concrete, Materials and Design, 31, 2010, pp. 2878-2883.

17. Algin, H.M., Turgut, P., Cotton and Limestone Powder Wastes as Brick Material, Construction and Building Materials, 22, Issue 6, June 2008, pp. 1074-1080.

18. IS: 13311 - Part 1, Assess the Quality of Concrete by Ultrasonic Pulse Velocity Method, Indian Standard Code of Practice, 1992. 